\title{
LANGUAGE SHIFT AND MAINTENANCE: A CASE STUDY OF KANI TRIBES*
}

\author{
Sreelakshmi KM
}

This paper aims to look into the status of the language maintenance and shifts in the Malampasha, a language spoken by the Kanikkar (ISO 639-3, kev) community in Kerala. The paper also intends to draw out some of the struggles that the Kanikkar community face in the wake of the dominating presence of Malayalam.

Keywords: Kani, tribes in Kerala, language shift, Malayalam, language maintenance, Kanikkar

\section{Introduction}

Though language loss was quite common in historic as well as pre-historic times, the number of languages that are facing endangerment or are extinct, have gone up since the sixteenth century (Dixon 1991a: 232). Quite evidently, colonization and genocide by European nations have been the primary cause. However, language loss of the present times, is of a different character. We begin our project on this note, where we grapple with the language loss of one such community in Kerala, a state that is quite distinctive for its health and educational indices but have been woefully ignorant of language loss.

India is home to nearly 2000 languages, out of which several languages are facing endangerment or extinction. According to the UNESCO, a language faces endangerment when it is spoken by less than 10,000 speakers. By this definition, in India, there are 600 languages that face endangerment and nearly 250 that have become extinct in the last sixty years.

Out of the 600 languages that face endangerment, nearly all of them are either languages spoken by nomadic communities or languages spoken by tribal communities. This is particularly significant in a state like Kerala, which has failed to officially recognize tribal languages. With Malayalam dominating $96.7 \%$ of the population, very little

\footnotetext{
* This paper is a part of the ongoing research on Documenting the language of Kanis in Kerala.
}

attention has been paid to the languages spoken by the tribal communities in Kerala. The State Government do not have an exact number regarding the tribal population in Kerala and the estimates vary from forty-eight to fifty-four. There is also widespread misconception that the mother tongues of several tribal communities such as Aranadan, Ulladan, Urali, Kaani, Kurichyan, Mullukuruman, Malaullda, Paniya, Adiya, Malpandaram and Viswan being treated as dialects. State driveninitiatives that are heavily invested in Malayalam has affected the survival of these languages.

While part of the problem arises from the violence of development and exclusion, language loss is also a natural by-product of migration, where minority communities must adjust to the constructed space of the state.

\section{The Context and Scope of Research}

In the reserved forest areas of Travancore in Kerala stays one of the aboriginal tribes of Kerala. Kani or Kanikkar were known for their close association with the royal Maharajas of Kerala. Settled in the Western Ghats of Kerala and Tamil Nadu, Kanikkars were originally known as 'MalaArayan'. As Matter (1883) states, "the tribes living toward the south of Travancore are most usually designated by this term Kanikkar, while those in the North are commonly called as 'MalaArayan'. It is possible that the change in the name and identity of the same tribe has everything to do with their social context. For example, it is believed that these hereditary land proprietors were too dominating that the co-existential of other tribes found it impossible with in the same land.

Despite having immense power, these royal forest caretakers had to start migrating with the end of the reign of kings. Today, the Kanis are known to be divided into two sections i.e. the Natukanis and the Malamkanis. Nattukanis are the people who are settled in the plains while the Malamkanis are those who reside in the hills. 
The Malamkanis are popularly identified as the propagators of arogya pacha meaning 'healthy green' or the 'plants that can provide evergreen health' which are botanically identified as Trichopus Zeylanicus. Such was their reputation that the tribe was awarded for their ethno medicinal findings at the UN sponsored World Summit on Sustainable Development. While scholars have paid attention to the community for their agricultural methods and natural reserves, the Kanikkars have been slowly losing their folklores and songs over the years.

Tribal bilingualism in Kerala is oral and therefore, majority of the speech varieties of the tribes have faced language loss due to standardization. There is a clear trend of moving away from mothertongues and favouring of Malayalam evident in Kanikkar and Kurichiyar communities. This is stark contrast to the efforts made in preserving the language of the Kanikkar communities in Tamil Nadu. In Tamil Nadu the language of the Kanis are known as "Kani-pasai" i.e, Spoken language (Miller and Narayanan Kani: 2004) while in Kerala, their language is known as "Malampasha" meaning language of the hills, ISO 639-3, kev. Very little work has been done on the Kanis of Kerala as compared to the literature that one finds in the Kani-pasai. According to Miller (2004 : 4), this is because "the people of Tamil Nadu have historically felt a devotion to their language to a degree unsurpassed by any other people in the world: some Tamilians even experience the Tamil language as a goddess" (Miller and Narayanan Kani 2004: 4). Miller states that,

The Kani's forest dialect of Tamil should be treasured, documented, and nurtured. Just as biodiversity is healthy for landscapes, preventing deforestation and desertification, so cultural diversity is valuable in human societies. As the Tamil language enters the Age of Cyberspace, let Her enrich Herself with knowledge and experience from the forest. One never knows when varied points of view and modes of perception might help a people to cope with new experiences and challenges. (2004:5)

The study looks into the critical juncture where Malampasha is slowly absolving the words from the dominant language.

\section{Methodology/ Selecting the Informants}

The study was conducted in the Kani tribal community in order to check their language shift and maintenance. Questions were asked to the informants to know in detail about their language attitude. The study was conducted in multiple levels. The data was collected through group discussion. As most of the informants were tribal, they were not very keen on the question answer process. For the informants, focused group discussions with 5-6 people were more productive. Secondly, the question answer method was used to extract many details about their language. The informants in the group included older generation people and younger generation, so that a clear variation in the language can be tracked.

For this whole research participants were selected in two ways. The first section the study started a general friendly talk with the community people. Out of them some of the tribes had an in-depth knowledge about their community's culture and tradition but the hardly uses their language for communication. While the other set of people included the elders in the tribe who too had an immense knowledge about their community and they speak their language. In the case of some of these elderly people they were aware of the fact that their language is different from Malayalam. At the same time others couldn't differentiate their language which is Malampasha with Malayalam. In these cases the interviews with this group of people held in a different way i.e., more in a naturalistic way so that their natural speech could be recorded. The older generation aged between 55-70years and the younger generation aged between 15-30 years. The total informants for this study were 10 older generations (Kanil, $\mathrm{K} 1$ ) and 10 younger generations (Kani 2, K2).

\section{Analysis}

\subsection{Phonological Features}

Sounds are the main features that undergo sudden shift while the native speakers try to imitate words from other languages. In the Kani phonology, such phonological change or shift can be seen in the sound $/ \mathrm{a} /$. The word beginning with /a/ sound is replaced with /e/ by the speaker. In the spoken language of the Malampasha such evident replace 
of the front unrounded open vowel /a/ with front unrounded close-mind vowel /e/ is visible. This phonological shift is seen both in the older generation and younger generation of Kani speakers.Even though the sound /a/ and /e/ are seen in the Malayalam spoken in Kerala, still the replacement of the /a/ sound with /e/ is more a feature of Tamil. As the Kani's are settled in the border areas of Kerala and Tamil Nadu, the influence of the both dominant language is seen in their language.

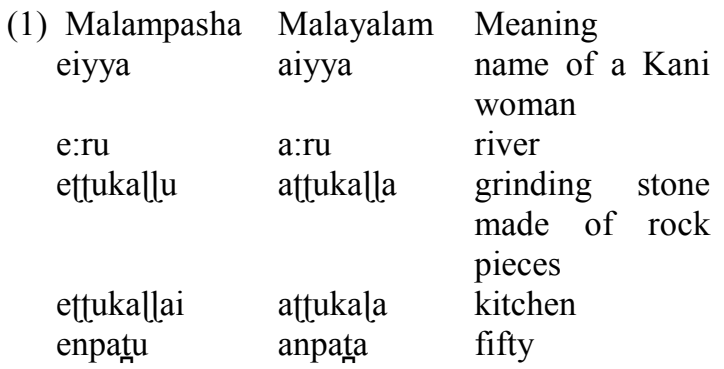

Table 1: Percentage of phonological variation of e $\rightarrow \mathrm{a}$ in Kani 1 and Kani 2 generation

\begin{tabular}{|l|l|l|l|}
\hline Generation & $\begin{array}{l}\text { No.of } \\
\text { Speakers }\end{array}$ & Sound & Percentage \\
\hline K1(Kani 1) & 10 & $\mathrm{e} \rightarrow \mathrm{a}$ & $6.75 \%$ \\
\hline K2 (Kani 2) & 10 & $\mathrm{e} \rightarrow \mathrm{a}$ & $7.55 \%$ \\
\hline
\end{tabular}

Similarly, the $/ \mathrm{v} /$, which is a labio-dental fricative sound, is mostly replaced in their language. Every time the kanikkar pronounce any word the $/ \mathrm{v} /$ sound is replaced with the plosive bilabial sound $/ \mathrm{b} /$. This feature is seen in the words starting with $/ \mathrm{v} /$ ending and in the middle positions too.

$\begin{array}{lll}\text { Malampasha } & \text { Malayalam } & \text { Meaning } \\ \text { bellijə } & \text { valijə } & \text { big } \\ \text { ebide } & \text { avide } & \text { there } \\ \text { biral } & \text { viral } & \text { finger } \\ \text { bellakkar } & \text { velakkar } & \text { servants } \\ \text { bentə } & \text { ventə } & \text { burned/cooked }\end{array}$

Table 2: Percentage of phonological variation of $\mathrm{b} \rightarrow \mathrm{v}$ in Kani 1 and Kani 2 generation

\begin{tabular}{|l|l|l|l|}
\hline Generation & $\begin{array}{l}\text { No.of } \\
\text { Speakers }\end{array}$ & Sound & Percentage \\
\hline K1 (Kani 1) & 10 & $\mathrm{~b} \rightarrow \mathrm{v}$ & $7.33 \%$ \\
\hline K2 (Kani 2) & 10 & $\mathrm{~b} \rightarrow \mathrm{v}$ & $8.66 \%$ \\
\hline
\end{tabular}

The retroflex approximant $/ \mathrm{d} /$ is not a feature in the Malampasha, in their tongue, older generation couldn't produce the sound. They mostly replace it with palatal appromxiamnt $/ \mathrm{j} /$. While the rest of the sound mention could still be produced by the Kanikkar but not the sound / $\mathrm{t}$. This might also give an evidence that this sound was absent in their language and the Kani's even after shifting to Malayalam, they are mostly not able to produce this sound during conversations. However, the younger generation / the present generation could produce this sound in their speech. While the older generation fail to or to say, try to retain some features in their language, the younger generation shifts their way of using language to Malayalam.

$\begin{array}{lll}\text { (3) Malampasha } & \text { Malayalam } & \text { Meaning } \\ \text { piju } & \text { pu.u } & \text { caterpillar } \\ \text { kuji } & \text { kuцi } & \text { pit } \\ \text { vaji } & \text { va.ji } & \text { path } \\ \text { čaji } & \text { ca.ji } & \text { an insect }\end{array}$

The above mentioned notable phonological changes give the evidence that this language also has similar notable features towards Tamil than to Malayalam. According to SIL International's study, the Malampasha has $60-70 \%$ of lexical similarity to the dominant language presently.

Table 3: Percentage of phonological variation of $j$ $\rightarrow_{\mathfrak{t}}$ in Kani 1 and Kani 2 generation

\begin{tabular}{|l|l|l|l|}
\hline Generation & $\begin{array}{l}\text { No.of } \\
\text { Speakers }\end{array}$ & Sound & Percentage \\
\hline K1(Kani 1) & 10 & $\mathrm{j} \rightarrow_{\mathfrak{l}}$ & $5.88 \%$ \\
\hline K2 (Kani 2) & 10 & $\mathrm{j} \rightarrow_{\mathfrak{l}}$ & $6.23 \%$ \\
\hline
\end{tabular}

\subsection{Case Markers}

Case markers are an important aspect in any language that defines the purpose of the sentences in the language through noun phrase, with respect to verbs. The case markers found in the language of Kanis will be also shown with noun phrases. Though many of the cases markers in Malampasha have undergone shift under the influence of Malayalam, certain case markers are also retained by the speakers.

$\begin{array}{lll}\text { Case } & \text { Marker } & \text { Example } \\ \text { Nominative } & \varnothing & \text { sita } \\ \text { Accusative } & \text {-inne } & \text { sitainne } \\ \text { Dative } & \text {-ikku/nikku } & \text { sitanikku }\end{array}$


84 / Language shift and...

$\begin{array}{lll}\text { Sociative } & \text {-dei } & \text { sitadei } \\ \text { Locative } & \text {-il } & \text { sitail } \\ \text { Instrumental } & \text {-aal } & \text { sitaal } \\ \text { Genitive } & \text {-nte } & \text { sitante }\end{array}$

In Malampasha the Nominative, accusative, dative, sociative case have been retained by the tribes. While case markers for locative, instrumental and genitive has been borrowed from Malayalam.

\subsection{Pronominal Forms}

The pronouns are the important feature in a language which is marker based on three features, gender, number and person. In the Malampasha, the Kanis used pronominal forms which appear similar to the Trivandrum dialect spoken in Kerala.

Table 4: The pronominal forms in both the languages are given below

\begin{tabular}{|l|l|l|}
\hline English & Malampasha & Malayalam \\
\hline $\begin{array}{l}\text { I (first person } \\
\text { singular) }\end{array}$ & Ein & na:n \\
\hline $\begin{array}{l}\text { We (first person } \\
\text { plural) }\end{array}$ & naya & nayal/nammal \\
\hline $\begin{array}{l}\text { You (second } \\
\text { person singular) }\end{array}$ & Ninge & ningal \\
\hline $\begin{array}{l}\text { You (second } \\
\text { person plural) }\end{array}$ & Ninga & avan/aval \\
\hline $\begin{array}{l}\text { He/she (third } \\
\text { person singular) }\end{array}$ & avanu/avabulu \\
\hline $\begin{array}{l}\text { They (third } \\
\text { person plural) }\end{array}$ & itinal & ava/iva \\
\hline
\end{tabular}

The pronominal system in the language shows that these terms have undergone a major shift towards Malayalam and Tamil. As this language has undergone a larger shift under the influence of the dominant languages, this is the present form is which the Kanikkar in the south uses the pronouns.

Table 5: Pattern of language shift over generation in pronominal forms

\begin{tabular}{|l|l|l|}
\hline Pronominal & Generation & $\begin{array}{l}\text { No.of } \\
\text { Speakers/Percentage }\end{array}$ \\
\hline $\begin{array}{l}\text { I (first } \\
\text { person } \\
\text { singular) }\end{array}$ & K2 & $10=4.55 \%$ \\
$10=7.33 \%$ \\
We (first & K1 & $10=5.75 \%$ \\
\hline
\end{tabular}

\begin{tabular}{|l|l|l|}
\hline $\begin{array}{l}\text { person } \\
\text { plural) }\end{array}$ & $\mathrm{K} 2$ & $10=7.55 \%$ \\
\hline $\begin{array}{l}\text { You (second } \\
\text { person } \\
\text { singular) }\end{array}$ & $\mathrm{K} 1$ & $\begin{array}{l}10=4.55 \% \\
10=5.66 \%\end{array}$ \\
\hline $\begin{array}{l}\text { You (second } \\
\text { person } \\
\text { plural) }\end{array}$ & $\mathrm{K} 1$ & $\begin{array}{l}10=6.75 \% \\
10=8.33 \%\end{array}$ \\
\hline $\begin{array}{l}\text { He/she (third } \\
\text { person } \\
\text { singular) }\end{array}$ & $\mathrm{K} 1$ & $\begin{array}{l}10=5.55 \% \\
10=8.33 \%\end{array}$ \\
\hline $\begin{array}{l}\text { They (third } \\
\text { person } \\
\text { plural) }\end{array}$ & $\mathrm{K} 1$ & $10=3.55 \%$ \\
\hline
\end{tabular}

\subsection{Possessive Pronouns}

Possessive pronouns are one of the important forms in the language that undergoes shift. They are formed when the personal pronouns and the interrogative pronouns are added to the genitive suffix.

Table 6: Possessive pronouns in Malampasha

\begin{tabular}{|l|l|l|}
\hline & \multicolumn{2}{|l|}{ Malampasha } \\
\hline Person & Singular & Plural \\
\hline First person & ente & naynadei \\
\hline Second Person & Ningei & Niyjadei \\
\hline Third Person & $\begin{array}{l}\text { abanikkə (M) } \\
\text { abilukkə(F) }\end{array}$ & $\begin{array}{l}\text { abanudei(M) } \\
\text { abiludei(F) }\end{array}$ \\
\hline
\end{tabular}

Table 7: Percentage of shift in the possessive pronouns in the Kani 1 and Kani generation

\begin{tabular}{|l|l|l|}
\hline Person & Generation & $\begin{array}{l}\text { No of Speakers/ } \\
\text { Percentage }\end{array}$ \\
\hline First person & K1 & $10=7.55 \%$ \\
& K2 & $10=8.66 \%$ \\
\hline Second & K1 & $10=7.33 \%$ \\
Person & K2 & $10=8.66 \%$ \\
\hline Third & K1 & $10=6.66 \%$ \\
Person & K2 & $10=8.33 \%$ \\
\hline
\end{tabular}

Even though, the language has undergone changes the terms in personal pronouns too are found that it has borrowed the suffixations in pronouns from Malayalam.

\subsection{Interrogative Pro-form}

In Malampasha, the interrogative pro-forms are mostly influenced by Malayalam language. These forms are the words that get mostly affected under 
the influence of the dominant language. But there is a certain difference in the sound system of the same word is seen in the Malampasha.

Table 8: The present Interrogative pro-forms in Malampasha

\begin{tabular}{|l|l|}
\hline English & Malampasha \\
\hline What & entə \\
\hline When & Eppera \\
\hline Where & Ebide \\
\hline How & Eyane \\
\hline Who & a:rə \\
\hline
\end{tabular}

Table 9: Percentage of variation in the use of the interrogative pro-forms in Kanil and Kani 2 generation

\begin{tabular}{|l|l|l|}
\hline $\begin{array}{l}\text { Interrogative } \\
\text { Pro-form }\end{array}$ & Generation & $\begin{array}{l}\text { No. of Speakers/ } \\
\text { Percentage }\end{array}$ \\
\hline What & K1 & $\begin{array}{l}10=6.55 \% \\
10=8.33 \%\end{array}$ \\
\hline When & K1 & $10=7.66 \%$ \\
& K2 & $10=8.55 \%$ \\
\hline Where & K1 & $10=6.66 \%$ \\
& K2 & $10=7.66 \%$ \\
\hline How & K1 & $10=5.75 \%$ \\
& K2 & $10=7.33 \%$ \\
\hline Who & K1 & $10=6.33 \%$ \\
& K2 & $10=7.55 \%$ \\
\hline What & K1 & $10=6.33 \%$ \\
& K2 & $10=8.55 \%$ \\
\hline
\end{tabular}

\section{Conclusion}

Bilingualism and multilingualism are one of the main reasons for language shift. The brief study on the language of the Kani shows a greater level of shift from their mother tongue to the dominant language. Malayalam is dominantly used in Kerala. However, when the tribes come in contact with the main land people even for their basic needs including purchasing, worships in temple, official visits, jobs, educations etc, they are forced to shift or to say learn the dominant language i.e. Malayalam. Moreover, the influence of media has also affected these minorities. Even though, the language policies in India safeguard many languages of the less spoken communities, it also fails to recognise minor communities. The present educational system that is followed is the three language formula. In the context of Kerala, these tribal children are forced to learn the dominant tongue. Trying to run along with the present fast growing world, with awareness to the need to protect their mother tongue would not only lead to the language shifts but also to language loss.

\section{References}

Abbi, Anvita. 2001. A Manual of Linguistic Field Work and Structures of Indian Languages. Lincom Europa

Abbi, Anvita (ed.). 1997. Languages of tribal and indigenous peoples of India. Indian Anthropologist, Vol. 27, No. 2 Delhi : Motilal Banarsidass. pp.89-91

Baiju, K.C. 2011. Tribal Development under Decentralised Governance in Kerala: Issues and Challenges, JOAAG, Vol. 6. No. 1.

Bose, N. K. 1977. Tribal life in India. National Book Trust. New Delhi.

Brown, R.M. 1994. Review of Endangered Languages [ed.] by R. H. Robins \& E. M. Uhlenbeck. International Journal of American Linguistics 60 (3).307-310.

Brown, R.M. 1989. Problemsand prospects of Tribal Development in North East India: In Economic and Political Weekly.Vol. XXIV. No.13 Bombay.

Census of India. 1991. Series 1, Language India and States. Registrar General and Census Commissioner, India.

Das, Pauline \& Raj Mohan L. 2014. Irula Folk Songs. Vol.16:6 June 2014.Languages in India.

Derhemi, E. 2002. Protecting Minority Languages: Sociolinguistic PerspectiveThematic Introduction, International Journal on Multicultural Societies. 4. (2). 153-164

DOBES Archive. 2006. DOBES Programme. www.mpi.nl/DOBES/dobesprogramme/

Dorian, Nancy. 1992, Investigating Obsolescence: Studies in Language Contraction and Death (ed), Cambridge, Cambridge University Press.

Dorian, Nancy. 1986. Gathering Language Data in Terminal Speech Communities, In Fishmanl (ed). The Fergusonian Impact. 555-575

Dixon, Robert M, W. 1997. The Rise and Fall of Languages. Cambridge: Cambridge UniversityPress.

Gardner, William. L. 2006. Language Use in the Epena District of Northern Congo. SIL International. 
86 / Language shift and...

Gippert, J, Himmelmann, N.P \& U, Mosel. [Eds] 2006. Essentials of language Documentation. Mouton de Gruyter. Berlin.

Himmelmann, Nikolaus. 1998. Documentary and descriptive linguistics. Linguistics 36:165191.

Himmelmann, Nikolaus. 2012. Linguistic data types and the interface between language documentation and description. Language documentation and conservation, 6:187-207. http://hdl.handle.net/10125/4503.

Lyer. Krishna. L.A. 1937.The Travancore Cochin Tribes and Castes. 3 Volumes. Madras: Madras Book Centre Publications.
Kulirani, B. Francis. 1988. Marriage among the Paniyan. In Marriage in India: Tribes, Muslims, and AngloIndians. B. B. Goswami, J. Sarkar, and D. Danda (ed.). Calcutta: Anthropological Survey of India. Pp. 255-260.

Kunhaman, M. 1985. The Tribal Economy of Kerala: An Intra-Regional Analysis. Economic and Political Weekly, Vol. 20, No. 11 (Mar. 16, 1985), pp. 466474. http://www.jstor.org/stable/4374180. (Accessed on 23/05/2014 03:04). 